\title{
Task-Based Language Teaching as A Method of Instruction in Teaching Speaking
}

\author{
Mita Nur Aflah \\ Sekolah Tinggi Bahasa Asing Pontianak, Indonesia \\ Email: mithanuraflah@gmail.com
}

\begin{tabular}{l}
\hline Available Online: \\
\hline http://www.jurnal.unublitar.ac.id \\
/index.php/briliant \\
\hline \\
\hline History of the Article: \\
\hline Received on 14 October 2020 \\
Accepted on 16 February 2021 \\
Published on 28 February 2021 \\
Pages 41-49 \\
\hline \\
\hline Keywords: \\
\hline Task-Based Language Teaching; \\
Speaking; Instruction \\
\hline DOI: \\
\hline http://dx.doi.org/10.28926/brilian \\
t.v3i4.569
\end{tabular}

\begin{abstract}
Abstrak: This paper aims to explore the theory on classroom instruction particularly Task-Based Language Teaching. It includes a short discussion of the definition and benefits of TBLT to help engaging students in a lesson by encouraging spoken interactions. In addition, teachers are encouraged to explore and experiment with TBLT in order to promote students active participation as well as to maximize opportunities for students to explore the target language. To strengthen the discussion, there is a guided framework to apply in the classroom as the subject matter for students to learn more effectively. Hopefully the paper could provide educators and instructors a method to use and to lead further studies for helping students to explore communicating in English. Moreover, this paper can also serve as a research reference in the field of classroom instruction, for instance in using TBLT to foster speaking skill.
\end{abstract}

\section{INTRODUCTION}

EFL learners need to have a lot of exposure in learning the target language. Since practice is available only in the classroom, thus learners need to speak while interact with their peers using the language. Teachers must encourage and stimulate the learners to speak. A way to stimulate learners to talk is providing extensive exposure to actual language through opportunities to explore the language.

There are two main issues to be considered in teaching speaking activities for an English class. The first issue is to decide what aspect of speaking skills to focus on along with the appropriate activities required. The second one is to identify technique or teaching strategy to teach. Thus, the teachers who are aiming to improve their students' ability to speak effectively need to find ways to provide learners with various kinds of learning activities so that they can learn in the ways which suit them best. The activities provide should help them gain the confidence to face interactive opportunities, without allowing the fear of making mistakes and appearing foolish to restrain them to communicate and develop speaking skills.

Taking those points above into considerations, there is an instruction that can be a solution to address the problem above. Researchers and experts in the field believed that a lesson or a syllable with Task-Based Language Teaching orientation can activate learners's potentials in order to boost their background knowledge while approaching the target language (Ellis, 2000; Nunan, 2004; Prabhu, 1992). Thus, this study was trying to focus on the theory on classroom 
instruction particularly Task-Based Language Teaching by using conceptual approach. It includes a short discussion of the definition and benefits of TBLT to help engaging students in a lesson by encouraging spoken interactions. There is a guided framework to apply in the classroom as the subject matter for students to learn more effectively. Hopefully the paper could provide educators and instructors a method to use and to lead further studies for helping students to explore communicating in English. Moreover, this paper can also serve as a research reference in the field of classroom instruction, for instance in using TBLT to foster speaking skill.

\section{DISCUSSION}

\section{A. Task-Based Language Teaching Approach}

Task Based Language Teaching (TBLT) has influenced the new trends in language teaching methodology since it emerges. It has appealed the interest of researchers, developers of curriculum, educationalist, teacher trainers and language teachers around the world (Branden, 2006). This interest has been motivated by the reality that 'task' is regarded as a build of equally importance to language teachers and to second language acquisition researchers (Ellis, 2000). The core concept of TBLT is a task. However, 'task' is viewed differently from many experts. First, starting from Prabhu (1987) states that a task is an activity that expect students to turn up a result from particular instruction through process of thinking which empower teachers to hold and supervise the learning process.

Another definition derived from Skehan (1996). He provides the thorough theoretical for task-based learning. He regards a task as an activity which belongs to the these criteria: (1) meaning is the main content; (2) solving communication problems; (3) comparing and adjusting to authentic activities; (4) completing a task; and (5) assessing task as a main goal. (p. 38)

Littlejohn (1998) suggested another definition about "task" belongs to any information or instruction for learners to be done, which has the primary aim of learning the foreign language." (p. 188)

The following is definition proposed by Richards and Renandya (2002), a task is an activity which students do using their available language and seeking to proper outcome. The types of tasks are educational game, solving a problem or experiences sharing. During the tasks, students are required to get involved in a processes of negotiating of meaning, paraphrasing and experimenting, in order to achieve a successful language development." (p. 94)

Later definition of task by Ellis (2005) as follow, a task is a work that stipulates learners to pragmatically process language to accomplish a result which will be assessed in terms of content. In sum, it requires learners to focus on meaning and practice their own linguistic resources. A task is aimed to create a resemblance language use, to the way language is applied in contextual situation. Same with other language activities, a task can influence productive or receptive, and oral or written skills and variety of cognitive processes. (p. 16)

Nunan (2006) makes a contrast between an authentic target of task (uses of language in real life) and a pedagogic task (what the learners do in class). Furthermore, he claims that tasks differentiate among other kinds of activities that have a non-linguistic outcome. Nunan defines a task as "a piece of classroom activity which provides students with comprehending, manipulating, producing or 
interacting in the target language, while their concentration is focused on activating their accuracy to express meaning rather than to manipulate form. The task should be outright, which can stand alone as a communicative act in its own right with a beginning, middle and an end." (p. 4)

Overall, these definitions underline the idea that each task covering the three aspects of process, participation and content. The process means the activity that the teachers and students carry out, participation concerns with learners' colleague during the process of doing the task and content is something that learners aimed. In sum, a task is a composition of instruction that expect learners to achieve an outcome using particular working procedures. Therefore, all experts underline the fact that communicative language use is involved in a task.

Ellis (2006, p. 20) asserts that the design of a task-based class involves the procedures or stages of a lesson that has its principal. There are three common principal stages have been proposed (Prabhu, 1987; Skehan, 1996; Willis, 1996). These phases reflect the chronology of a task-based lesson.

The following is a framework proposed by Willis (1996, p. 52):

Figure 2.1. A Framework of Task-Based Instruction by Willis (1996)

\begin{tabular}{|l|l|}
\hline $\begin{array}{l}\text { Pre- } \\
\text { Task }\end{array}$ & $\begin{array}{l}\text { Introduction to topic and task: Teacher has a duty to explore } \\
\text { the topic, mark useful words and phrases, help and guide } \\
\text { students to comprehend task instructions. }\end{array}$ \\
\hline $\begin{array}{l}\text { Task } \\
\text { Cycle }\end{array}$ & $\begin{array}{l}\text { Task: Students carry out the task in pairs or small groups. } \\
\text { Teacher monitors the process. } \\
\text { Planning: Students making the report to the whole class (orally } \\
\text { or in writing) how they did the task, what they decided or } \\
\text { discovered. } \\
\text { Report: Some groups present their report to the class, or } \\
\text { exchange written reports and compare results. (E.g. receive } \\
\text { feedback on their level of success on completing the task). }\end{array}$ \\
\hline $\begin{array}{l}\text { Language } \\
\text { Focus }\end{array}$ & $\begin{array}{l}\text { Analysis: Students review and discuss specific features of the } \\
\text { text or transcript of the recording. } \\
\text { Practice: Teacher creates practice of new words, phrases and } \\
\text { patterns occurring in the data, either during or after the analysis. }\end{array}$ \\
\hline
\end{tabular}

Another framework proposed by Ellis (2006, p. 20) as follow:

Figure 2.2 A Framework for Designing Task-Based Lesson

\begin{tabular}{|l|l|l|}
\hline \multicolumn{1}{|c|}{ Phase } & \multicolumn{1}{c|}{ Example of Options } \\
\hline Pre Task & $\bullet \quad$ Framing the activity (e.g. establishing the \\
& & outcome of the task) \\
& - Planning time \\
& - Doing a similar task \\
\hline During Task & - Time pressure \\
& - Number of participants \\
\hline Post Task & - Learner report \\
& - Consciousness-raising \\
& - Repeat task \\
\hline
\end{tabular}




\section{The Pre-Task Phase}

Ellis $(2006$, p. 21) declares that the aim of the pre-task phase is to let learners do a preparation before performing the task in order to promote acquisition. It deals with variety of activities that teachers and learners can implement before doing the main task. Ellis (2006) also elaborates Skehan (1996) ideas about 'general cognitive demand' during pre-task phase into procedural action that can be done in the following ways; (1) supporting learners in doing similar task that they will do during the task stage of the lesson, (2) asking learners to observe a guide of how to carry out the task, (3) involving learners in non-task activities in order to let them practice before performing the task or (4) planning a strategy of the main task performance (p. 21).

In line with Ellis, Prabhu (1987, p. 44) emphasises that the aim of pre-task is to assure that a task is clearly perceived by learners and the strategies for solving the task as well as the language needed for purpose is available for recall and reapplication. Thus, it is clear that the pre-task acts as a tool for teacher to measure performance of the learners with the expectancy that it can stululate learners' self-regulation to perform the main task (Ellis, 2006, p. 22). Therefore, it is easier for learners to recognize and examine those features in the model texts (Ellis, 2006, p. 23).

Furthermore, Nunan (2004, p. 31) also suggests that the teacher can create a list of schema-building tasks that covers the topic, the task context, and provide the key vocabularies and expressions that the learners will use to finish the task.

\section{The During Task Phase}

Prabhu (1987, p. 28) states that the second phase (read: during task, task cycle or main task) is task-based interaction in the classroom that used activities that are able to engaged learners with understanding meaning, and get on with language forms as the requirement of the process.

Prabhu (1987, p. 25) further claims that such activities can be seek by every student individually or in groups with guidance from the teacher if necessary on specific points. The methodological option during-task phase described by Ellis (2006) who proposed two basic kind 'task-performance' there are a some of 'process options'.

Time limitation of a task affects the meanings and the language that learners will produce which focuses on fluency. When learners are working on tasks, they will be aware of time limit. It makes learners became more focused with conveying what they want to say under the time limit and less cautious with language accuracy. In contrast, without the time limitation, learners will have longer time to think about the language and the content that they produce. The language and the content will be more accurate. Thus, it is good to approach this task with degrees of time constraints.

From the descriptions above, it is clear that task-based teaching can be useful approach due to the primary points in TBLT activities are students-centred, including practices that stimulate learners to involve in forming and managing the subject, and social practices as a resolve of social trouble (Ellis, 2006, p. 29).

The Post-Task Phase 
In the post-task phase there are three major pedagogic goals; (1) giving an exposure for doing same task, (2) promoting task reflection and (3) encouraging the interest from the problematic learners (Ellis, 2006, p. 36). Ellis further explains that, a repeat performance can improve students' fluency. In addition, triggering learners to do performance reflection may donate to the improvement of the metacognitive strategy. Students might also foster their task performance by asking students to review the task. The teacher will be able to determine whether will use the same tasks or not by having that information. Furthermore, to prevent the students developing fluency without paying attention to accuracy, the posttask stage is necessary to apply. (Ellis, 2006, p. 38)

Based on the information above, learners should complete the task through preparation that can reduce their anxiety. They can do their best by having more time to think during the task. It is expected that learners will not be anxious in speaking. Through TBLT, the focus on meaning is the main point instead of focus on form. As a result, learners will not be afraid of making mistakes while carry out the task which can improve their speaking ability.

Overall, a framework of a task-based lesson is necessary for both teachers and students. It gives a clear guide for a lesson and in order to boost creativity and variety in each phase. Using those frameworks to implement TBLT are not the only way. Teachers should do explore the framework to create their own framework that appropriate for their own teaching.

\section{B. Task-Based Language Teaching for Teaching Speaking}

In order to understand the context of the language and to use it in real life situation, language teachers need to realize the significance of the student-centred and the need for TBLT. Language is the vehicle for accomplishing the aim of the task, but the meaning and communication is primary. In task-based language instruction, there are some goals. Willis (1996, pp. 35-36) proposes eight goals:

a. improving learners' confidence in exploring the language;

b. providing learners with spontaneous interaction;

c. giving chance for learners to learn from others;

d. giving chances for learners how to negotiate turns to speak;

e. engaging learners in using language purposefully and cooperatively;

f. encouraging learners to participate in a real interaction,

g. giving chances for learners to experience with communication strategies; and

h. fostering confidence of learners to achieve the goal of communication.

Based on those purposes, the speaking activities provide by the teacher should covers all of them. Creating exposure for students to speak the target language can be done by giving collaborative work learning environment, authentic tasks and materials, and shared knowledge (Kayi, 2006). Moreover, it is well known that more negotiated interaction is produced than in teacher-fronted classrooms when learners work in groups (Beglar \& Hunt, 2002). If a task forming greater negotiation of meaning, it becomes more advantageous for the development of inter-language. Obviously, involving in negotiation will produce higher degrees of comprehension and good input as a result of paraphrasing and lexical substitution. 
Nowadays, approaches to second language teaching methodology prioritize student autonomy and student-centred instruction as effective ways of learning. Due to the fact that (a) students are responsible for their own learning; (b) they are responsible in shaping their learning style; (c) there is teacher-student and student-student interaction; (d) there are many brainstorming activities, pair work, and small-group work; and (e) the teacher's role is more like a partner in the learning process, an advisor, and a facilitator of learning than an instructor or lecturer who spoon-feeds knowledge to learners (Shehadeh \& Coombe, 2009). Those points must be provided in the L2 classroom. Therefore, task-based language instruction can be a suitable approach for applying those principles in the second language classroom.

TBLT approach encounters the challenging task constantly faced by language teachers to attract and stimulate motivation of students to learn. In taskbased teaching, tasks are activities where the students use target language for a communicative purpose. Tasks are goal oriented; the underline is in understanding and suggesting meanings to complete the task effectively. When students are carrying out the tasks, they are using language in an effective way. However, teacher must be aware of number of considerations on the type and design of the communicative task.

In order to design the interactive task, the teacher may make use of Willis' (1996, pp. 26-27) detailed list of activities that teachers can take into account when creating tasks:

- Listing: brainstorming

- Ordering and sorting: sequencing and categorizing

- Comparing and matching: finding similarities

- Creative: project work

- Problem solving: analysing and decision making

- Sharing personal experiences: expressing opinions

From the list above, it can be seen that TBLT provides a construction framework for both teaching and review. Thus, when a series of connected, a variety of benefits occur when themed tasks are arranged in such a way that led students to promote a real-world interaction and practise at an intensifying level of complexity. These covers a purpose-driven vocabulary recycling and language forms, an increased sense of motivation, a marked increase in communicative confidence, scaffold autonomy-building and a truly student-centred classroom.

The challenge of task-based teaching and learning is providing learners in a various tasks to stimulate acquisition. Learners have some pedagogical needs which require a different teaching approach. For instance, learners need to involve in psycholinguistic and metalinguistic processes such as repeating, noticing forms, hypothesizing and conceptualizing rules, as being conducive to the language acquisition process which have been found by research. Beglar \& Hunt (2002, pp. 101-102) also claim that learners should be actively engaged in using communicative strategies, such as clarification, confirmation, comprehension checks, requests, repairing, reacting, and turn taking. Therefore, to guide learners to move forward in their language development, variety of opportunities to modify and restructure interaction until mutual comprehension should be accomplished. 


\section{The Overview of Previous Study}

There are some previous studies dealing with task-based application in the ELF classroom are summarised in this section to give an overview of what researcher had done so far in this new field.

Tindall (2015) conducted a study in UK. The study aimed to find out the outcome of applying task-based learning to a group of 10 pupils in a secondary school, which focus on motivation, student progress and perceptions. He found that task-based learning can be an option, as an approach to more traditional methods of second language teaching and had remained relatively unexplored in the UK foreign language classroom. The findings showed that there was an positive improvement in students' motivation and perceptions. However, using this approach can be a lot more time-consuming and the researcher still had to use some control over the language use of the students during the task.

Achmad and Yusuf (2014) confirmed the findings that the task was successfully implemented. The findings had supported the pair-work implementation of in ELT classrooms. However, the outcomes can be generalized to other settings due to the fact that the research focusing only on classroom activity observation and presenting two excerpts from the observation. Due to these limitations, it is suggested that more similar research is necessary to support the findings from this study. It is also suggested that more observers are needed to monitor the pair-work activity to gain more information and further consistency of the results.

Tabrizi and Nasiri (2011) reported a study of Iranian EFL from intermediate level found that the experimental group students, who experienced teaching speaking through task-based principle, performed preferable than the control group. It was also stated that in speaking development, gender was not a determining factor in task-based approach. To recapitulate, task-based approach had effect on the students' speaking proficiency, while gender has an insignificant effect on speaking ability development.

Kirkgoz (2011) investigated the principles of Task-Based Learning which is combined with the use of technology for the first-year student teachers of English in Turkish higher education. The data showed that students speaking skills had improve, and they had positive attitude on the integration of technology in the teaching process. The study also reported that the use technology (video camera) had a noticeable impact on students' perception and the assessment of their speaking tasks.

Meas (2010) identified the effect of teaching English through TBLT. The study claimed that using task-based might be more workable in the setting situation. However, if a more task-based approach is adopted in this setting in the future, some potential problem such as the teachers' lack of comprehension of TBLT, traditional examination, the nature of the course book and teaching materials, etc. must be dealt with in advance.

Kim (2003) studied to find out that task-based test was very beneficial for actual inferential demands in language classrooms as it employed complex, integrative, and open-ended tasks. Moreover, authenticity was useful to fulfil the assessment by bridging the gap between real-word situation and the way they 
were tested. However, scoring performance was not a simple task of copying a real-world activity to a test. By its nature, task-based assessment involved a lot more variables affecting test scores and the interpretation of those test scores.

Lee (2002) investigated the students got benefit from online task-based activities due to the access of different functional skills to build and negotiate meaning collaboratively. Online discussion using TBI have created a new arena for Second Language Acquisition, that is, a place where learners can get input and produce output by negotiating. Blending TBI with online chat can be a valuable model of using online technologies to transform and enrich the Foreign Language learning experience. This study proposed that the combination of online interaction and TBI empowered communication skills of students by promoting an environment which they responded to real-time conversation about topics relevant to their interests.

In sum, Task-Based Language Teaching is a beneficial approach to use in order to develop foreign learners' performance and achievement in using English. It is more learner-centred, allows more meaningful communication, and builds extra linguistic skill. Moreover, learner will feel less anxiety because they are familiar with the task. It helps them to be engaged fully in the classroom and motivate them to better their performance in learning a language.

\section{CONCLUSION}

In conclusion, task-based framework promotes students active participation in the activities and help teacher to manage classroom interaction as well as to maximize opportunities for students to explore the target language which later on can increased their positive attitude for language learning.

\section{SUGGESTION}

The result of this research can be used as a reference to do future studies dealing with improving students ${ }^{\text {ee }}$ speaking competence through Task-based language teaching approach. Moreover, it is expected to provide a model of the task-based approach framework that will be applied in the classroom by the researcher, other teachers and practitioners.

\section{REFERENCES}

Achmad, D., \& Yusuf, Y. Q. (2014). Observing Pair-Work Task in an English Speaking Class. International Journal of Instruction, 7(1).

Beglar, D., \& Hunt, A. (2002). Implementing Task-Based Language Teaching. In J. C. Richards \& W. A. Renandya (Eds.), Methodology in Language Teaching: An Anthology of Current Practice. Cambridge: Cambridge University Press.

Branden, K. V. d. (2006). Introduction: Task-Based Labguage Teaching in a Nutshell. In K. V. d. Branden (Ed.), Task-Based Language Education: From Theory To Practice. Cambridge: Cambridge University Press.

Ellis, R. (2000). Task-Based Research and Language Pedagogy. Languange Teaching Research, 4(3), 193-220.

Ellis, R. (2005). Instructed Second Language Acquisition A Literature Review. New Zeland: Research Division Ministry of Education. 
Ellis, R. (2006). The Methodology of Task-Based Teaching The Asian EFL Journal Quarterly, 8(3), 19-45.

Kayi, H. (2006). Teaching Speaking: Activities to Promote Speaking in a Second Language The Internet TESL Journal, 12(11).

Kim, H. (2003). Task-based Performance Assessment for Teachers: Key Issues to Consider. Columbia University Working Papers in TESOL \& Applied Linguistics, 4(2).

Kırkgöz, Y. (2011). A Blended Learning Study On Implementing Video Recorded Speaking Tasks In Task-Based Classroom Instruction. The Turkish Online Journal of Educational Technology, 10(4).

Lee, L. (2002). Enhancing Learners' Communication Skills through Synchronous Electronic Interaction and Task-Based Instruction. Foreign Language Annals, 35(1).

Littlejohn, A. (1998). The Analysis of Language Teaching Materials: Inside the Trojan Horse. In B. Tomlinson (Ed.), Materials Development in Language Teaching Cambridge: Cambridge University Press.

Meas, S. (2010). Investigating the Feasibility of Adopting Task-based Language Teaching in a University Setting in Cambodia. Masteral of Education, University of Hong Kong, Hong Kong.

Nunan, D. (2004). Task-Based Language Teaching Cambridge: Cambridge University Press.

Nunan, D. (2006). Task-Based Language Teaching in the Asia Context: Defining 'Task'. The Asian EFL Journal Quarterly, 8(3), 12-18.

Prabhu, N. S. (1987). Second Language Pedagogy. Oxford: Oxford University Press.

Prabhu, N. S. (1992). The Dynamics of the Language Lesson. TESOL Quarterly, 26(2), 225-241.

Richards, J. C., \& Renandya, W. A. (2002). Methodology in Language Teaching: An Anthology of Current Practice. Cambridge: Cambridge University Press.

Shehadeh, A., \& Coombe, C. (2009). From Theory to Practice in Task-Based Learning. TESOL Quarterly.

Skehan, P. (1996). A Framework for the Implementation of Task Based Instruction. Journal of Applied Linguistics, 7, 38-62.

Tabrizi, A. R. N., \& Nasiri, M. (2011). The Effect of Using Task-Based Activities on Speaking Proficiency of EFL Learners. The Third Asian Conference on Education Official Proceedings, 333-345.

Tindall, A. (2015). A critical exploration into the effects of task-based learning upon a year 10 French class of demotivated students: an Action Research project. Journal of Trainee Teacher Education Research, 6.

Willis, J. (1996). A framework for task-based learning. Harlow: Longman. 